\title{
Student musicians' experiences of reflexivity during internships: Personal narratives and complex modalities
}

\section{Abstract}

A presumption behind work integrated learning activities such as internship programs is that student thinking will shift as a result of their exposure to industry practice. We wondered if all students experience this change in the positive sense that teachers expect. To examine this presumption we asked to what extent and in what ways students reorient their thinking about self and identity as a result of an internship experience. Analysis of student reflections following a structured internship program lead us to believe that not all students experience a shift in thinking that their personal narratives speak instead to a complex relation of modalities.

Keywords higher education, music, career transition, work integrated learning, WIL, conservatoire

\section{Introduction}

Musician identity is formulated through a series of complex interactions involving a totality of students' experiences. When undertaking music studies, students are involved in a range of formal and informal learning experiences (Lebler, 2008). They bring a wealth of experience from their normal life activities, they may be involved in external music making, and they are likely to hold part-time and casual jobs in support of their studies (Australian Bureau of Statistics, 2010; Department for Business Innovation and Skills, 2013). The role of internship programs is to enable students to experience authentic workplace experiences. These experiences provide a fertile space that affords reflection on musical studies and life goals. Combined, these experiences contribute to students' sense of being and to the manner in which they see themselves as music workers.

At the conservatoire from which this study is reported, students undertake four years of intensive musical studies. Students become 'experts' at learning within this environment (Reid et al., 2011) and their sense of self as a student musician is actively developed. However, we have noted that formal studies alone cannot lead to an understanding of professional work as students are firmly embedded in a student community of practice rather than a professional community of practice. 
Internship programs are an example of work-integrated learning, or WIL. Encouraging students to undertake internship programs is a means of enabling them to cross the border from the student community to the professional community and to re-consider how their current musical identities may be reformed within professional environments. Or so we think. Most reports on internship programs positively relate these with the ability to integrate easily into real work environments upon graduation (ACEN, 2015). Indeed, a presumption behind internship programs is that student thinking will shift as a result of exposure to industry practice. Our previous conclusions are not dissimilar. In a prior article, for example, we reported on the leadership skills developed during the internship process, providing evidence from a whole data set (Rowley, Bennett \& Reid, in press). However, an analysis of the main outcomes of a group analysis does not reveal individual difference.

In this paper we wish to acknowledge and report on those students who gain huge personal insight from the programs and also those for whom little change is observed. Reported here, analysis of student reflections following an undergraduate internship program led us to believe that not all students experience the shift we may have expected, and that their personal narratives speak instead to a complex relation of modalities. Here we look at the creation of musician identities as explained by the students' reflections. Their complex ideas may be understood from a multiplicity of theoretical and practical perspectives including narrative theory (Gaunt \& Westerlund, 2013), communities of practice (Wenger, 1998), and reflection on and reflexivity in experience (McIntosh \& Webb, 2006; Schön, 1983).

To explain what happens during the internship program we use the idea of multiple modalities. Our whole-cohort data show evidence that the program enables students to rethink, or expand, what they imagine their musical future to be; develops a better current understanding of their musical values; provides opportunities for students to develop leadership skills, to make sense of human interactions in work environments and to make sense of the musical ideas that they have already developed; affords a situation in which their musical knowledge is conceptualised; and facilitates purposeful engagement and change. The sum of these complex actions and thoughts contributes to the evolution students' personal and musical identities. 
Student narratives are drawn from a series of reflective statements that form part of the internship program requirements. The inclusion of reflection is to support students' integration of the musical knowledge and experience developed through their formal studies and from the workplace issues and activities they have recently experienced. In this way, we hope that students will be able to show us how their thinking about their musical identities and activity may have changed or shifted.

We employed complexity theory to understand what happened in students' formal learning spaces, in their informal engagements with peers, and in students' workplace experiences. The logic of complexity theory within educational research on identity development comes from its acknowledgement that stability, like career preview is "in some ways illusory" (Davis \& Sumara, 2008, p. 35). As such, it is "able to acknowledge the insights of other traditions without trapping itself in absolutes or universals” (p. 36). In many ways such acknowledgement describes a 'growth' mindset (Rowley \& Munday, 2014) in which identity develops as a process of integration and formation not bounded by discipline, sector or traditional ways of working.

Complexity theory evolved out of systems theory and considers systems in relation to the interrelationships between component parts. Our earlier work with this framework identified three connective, leadership-related elements exposed by student musicians' movement through multiple domains: namely, bridging theory and practice; flexibility; and reorienting learning as career relevance is realised (Rowley, Bennett \& Reid, in press). These findings are in line with Manson's argument (2001) that diverse situations often cohere as a result of approximately three elements.

Within the complexity theory framework, analysis was undertaken deductively through a search for three reflective themes derived from Piihl, Rasmussen and Rowley (2015): bridging the gap between theory, policy and practice; self-reflection; and future learning areas. We sought to answer the following research question:

To what extent and in what ways do students reorient their thinking about self and identity as a result of an internship experience? 
In the following sections we establish the rationale for the study and describe our approach. We then present and discuss the findings, beginning with evidence of the three reflective themes and then discussing students for whom the internship experience did not appear to develop a shift in thinking.

\section{Rationale}

Worldwide, higher education institutions are rethinking their approaches to teaching, learning and research in line with diverse student bodies, technological innovations, a rapidly changing labour market, and the demand for work-ready, socially responsive and skilled graduates. To maintain a competitive edge in a volatile and unpredictable market, many progressive institutions engage with external stakeholders including community and industry competitive edge. Such engagement extends across research partnerships and beyond discipline knowledge to incorporate work-based, practical learning experiences that complement students' theoretical skills and knowledge (Gribble, 2014).

Work-integrated learning (WIL) such as an internship experience "encompasses a range of activities that integrate learning and practice” (Ferns, Campbell \& Zegwaard, 2014, p. 1). Whilst WIL has received justifiable attention over recent times, the overwhelming reporting bias on positive workplace experiences has fuelled assumptions that WIL experiences, regardless of structure or duration, deliver positive benefits for students. Few would dispute that professional behaviours and skills are enhanced through industry placements and the involvement of industry in program delivery (Mason, Williams \& Cranmer, 2009). However, as Billett has argued (2011a, p. 1), “merely providing practice-based experiences for students is insufficient unless those experiences are enriched through preparation, engagement and opportunities to share and reconcile what has been contributed by these experiences".

This reconciliation is a necessary enabler for reflective practice to develop into reflexive practice.

The need for WIL is heightened in disciplines such as music, where graduates are likely to encounter portfolio and non-linear careers featuring multiple concurrent roles (Bennett \& Bridgstock, 2015). For these graduates, professional and personal identity revisions are made in line with each new venture (Bridgstock, Goldsmith, Rodgers \& Hearns, 2015). As observed by Solomonides and Reid (2009), identity is experienced as simultaneously singular and multiple by both practising and aspiring musicians. This is because identity development is informed by various life domains, including cultural 
and social context, and because the behavioural aspects of musician identity are influenced by musical experiences before and during higher education studies (MacDonald, Hargreaves \& Mielle, 2009).

The rationale for this study then, is the need to prepare students for the demands of obtaining, creating and managing work over the career lifespan, and the resolve to ensure an informed and quality music internship program experience that helps prepare students for future work.

\section{Approach}

The internship program reported here challenged students to apply their knowledge and skills in a professional practice setting and to reflect on these experiences in terms of their past and future learning and action. The structured undergraduate internship program was located at an Australian conservatoire. With the aim of developing professional skills and knowledge alongside awareness and knowledge of the creative industries and associated workplace practices, the credit-bearing internship was offered to music education and performance students in their $3^{\text {rd }}$ or $4^{\text {th }}$ (final) year of study.

Between 2013 and 2015, 152 third- and fourth-year undergraduate music students participated in the internship program. The two assessment tasks comprised a portfolio and a presentation; both were required tasks. Students made their presentations in front of an academic (the marker), and representatives from the arts industry attended some of the presentations. From the 152 cases, 25 complete cases - every $6^{\text {th }}$ case - were selected for analysis. Of the 25 cases, 18 came from the B.Mus. (Performance) program, three from the B.Mus. (Music Education) program and four from the B.Mus. Studies program. Fourteen of the students were in their final $\left(4^{\text {th }}\right)$ year of study and the remaining 11 students were in their $3^{\text {rd }}$ year. Ethical approval was obtained prior to commencement of the study and participation was voluntary.

Given the flexible nature of creative industries work, the 60 to 80 -hour voluntary internships could be undertaken on a full-time or part-time basis and might involve more than one employer; placements were selected according to the interests, expertise and availability of both students and employers. Potential internship employers came from performance, education, music sales, festival direction, 
broadcasting, arts management, venue operation, music teaching, concert promotion, recording, music promotion, and community music. Employers interviewed interested students directly.

Students developed and presented an online portfolio based on their internship learning. Both the portfolio and presentation were assessable tasks. Students were provided a template of guided questions to assist in the portfolio's development and their completed portfolios tended to be around 2,000 words in length. Each year, eight students spoke about their experiences during an industry forum and all other students shared their experiences with peers during a shared presentation session.

Reflective themes derived from Piihl, Rasmussen and Rowley's (2015) multi-disciplinary incremental framework for higher education teachers emphasise potential tensions that could emerge during the often-fluid movement from student to professional. The tensions between the different roles serve as a source of transformation and motivation for students as they move into the role of professional and are required to act reflexively with stakeholders such as employers, clients and peers. Therefore, the students engaged in online reflections both during and following completion of their internships and they submitted their final reflections for assessment. Students reflected on work plans and activities, learning, personal strengths and weaknesses, theory, policy and practice, self-reflection, and future learning areas. The three reflective themes relevant to this paper are included below together with the themes in which they were housed: Relating theory, policy \& practice; Self-reflection; and Future learning areas.

\section{Results and discussion}

\section{Relating theory, policy and practice}

It may be argued that formal studies rarely lead to a deep understanding of a student's potential professional future self and that experiential learning provides a conduit to realising the connection between the two. The data in this section reveal how students experienced the learning space between formal music study and internship work experiences and how, in turn, they transformed their thinking from situation to situation. 
After completing two years of aural and harmony, one can start to think, will I ever really use a lot of this highly detailed and difficult musical knowledge I have learned [once I am in] in "the real world"? The answer is yes. After watching for many hours [of] rehearsals I became very aware of those who had a lot of musical knowledge, and those who found it a lot harder. (Gemma)

For higher music education to support student musicians in the development of their musician identities there needs to be "a dynamic interplay between the two notions of who the person is becoming and what they are coming to know" (Reid et al., 2011, p. 15). Central to this are experiences, such as those reported here, that enable exploration of music and self within the context of a professional community.

The theories, policies and teacher practices taught in lectures and tutorials have become more applicable after my internship. This was clearly seen when reflecting upon teachers' pedagogical approaches as well as reflecting over my own actions, thoughts and decisions when teaching. (Anthony)

I wanted to learn valuable industry knowledge to further my understanding of a competitive industry to propel my career ... to network with people in my industry, who I can forge connections with thus furthering my career. (Gemma)

For many workers the organisation provides the main external influence, which in most commercial situations is saturated with complex ideas and relationships. In fact, realising the potential to enhance learning through the integration of theory and practice is arguably the key to the successful future realisation of skills, knowledge and competence in a particular field (Wren \& Wren, 2009), as seen below.

When interning at [arts space] for the [arts festival], I realised the scope of tasks and responsibilities that are required for running an arts organisation - from administrative tasks to hands on artistic collaborations. ... Completing these administrative tasks furthered my knowledge regarding the variety of interdisciplinary art and art making occurring in [city], Australia and internationally. (Maggie)

Whilst professional programs must prepare workers to become professional practitioners in their chosen field of practice (Wren \& Wren, 2009), recognising the relevance and meaning of learning is an important step for students (Deci \& Ryan, 1985). For Oliver and Danny, this realisation came during their internships. 
Having previously gone through the music history and musicology courses in earlier years at the conservatoire, it was extremely satisfying to form an added dimension to the knowledge that I already had and will continue to gain ... it was much easier to form a detailed understanding of more specific areas: for instance, looking at specific nations in the context of a musical period... (Oliver)

... through my music technology courses throughout first and second year, I learnt about many elements of recording, editing and equipment. This knowledge acted as a foundation that could then be directly applied to many of the tasks required at this internship. (Danny)

For some students, including Frank, the relevance of formal learning was a surprise.

Throughout this internship experience, I was frankly a little surprised at the ways in which teaching from the Conservatoire aided or was developed by my time spent at [the radio station]. (Frank)

Determining relevance to future can be "the trigger for encouraging students to think creatively about their future lives and careers" (Bennett, 2012, p. 28) and to more open-ended, boundaryless thinking. Relevance is also aligned with motivation. As Csikszentmihalyi (2007, p. xix) has argued, "within their domain of interest, all creative individuals love the task that engages their whole energy". For these students then, the internship experience formed an important step in their professional development.

\section{Self-reflection}

Studenthood can be thought of as a psychological stage of development enacted within broad formal and informal learning situations including experiential learning contexts such as internships. In such contexts, students "come to learn through experiences in educational and practice settings and reconcile and integrate the contributions of those experiences" (Billett, 2011a, p. 2). In contrast with the external view offered by their studies, an internship exposes students to an "inside perspective" (Mason, 2014, p. 158) on future work. This can generate critical reflexivity or self-awareness of practice through which students come to a conscious understanding of their dispositions (Bourdieu \& Wacquant, 1992). As such, reflexivity, in contrast to reflection, can be realised as an ability or competency, a critical approach to professional practice, and an approach that acknowledges the dynamic relationship between thoughts and feelings (D’Cruz, Gillingham \& Melendez, 2007). 
Shown below, for Maggie the critical approach came through exposure to emerging artforms and the exciting potential for these innovative practices to form part of her future practice. Claire's experience was of potential barriers to innovation and the need to trouble traditional ways of doing and being, and Gemma was frustrated to have been confined to only the artistic aspects of creative practice.

Viewing, researching and comparing current productions and programs gives an indication as to what artforms are currently developing. Presently, interdisciplinary artforms hold an important role in challenging and developing new forms of artistic expression. (Maggie)

I worry that this [radio] station would be unlikely to allow me to create such a program as it [is] quite outside the norm of what is aired. ... I have learnt that conformity even in the arts industry is expected. (Claire)

I would have liked to learn how the administrative side of artistic companies works, as this is a good area to have experience in if I need to work in an administrative job to subsidise my performing income in the future ... this internship was restrictive and too structured. (Gemma)

Many students recognised an ability or competency, or conversely an inability or weakness - a competence yet to be developed. This can be seen in the following reflections.

It was an evolving learning curve and I always had a new task to complete. My first impressions were that I was a bit in over my head ... but I quickly caught on ... as I learnt how to communicate and act with other staff members and the cast. (Sally)

Symphony orchestra rehearsal ran for an hour, and my brain was fried at the end of it ... my performance ability is exactly why I am on the career path I am. (Paul)

I have learnt that sometimes to my detriment I am determined to do things on my own. What I realised is that, especially at my age, I often don't have the answers or don't know how to do things and that I shouldn't be afraid or embarrassed to ask for help from others who have more experience. (Lucy)

For these students, a weakness or fear was reported as a change in behaviour for which the student would become responsible. We can define this as student agency, prompted through enhanced confidence (Sally), the desire for performance fitness (Paul) and the realisation that asking questions is a positive part of learning (Lucy). 
Students' development as critically reflexive practitioners is most often discussed in relation to negotiating the transition, or transitions, from study to work. For it to influence learning, however, the reflexive career modality needs to develop during studenthood. As such, reflexivity is an important feature of the transition of knowledge from (internship) work to study and back into an individual's future-oriented practice and goal setting. Steven and Gemma reveal this thinking in their reflections.

I have also obtained a better understanding on what is involved in producing music and have applied these skills to the organisation of my own concerts and performances. (Steven)

This internship has shaped my whole year as a performance student and is turning out to be a huge stepping-stone into the professional world. This internship has helped develop my goals as a musician. (Milly)

The dynamic relationship between thoughts and feelings (D’Cruz, Gillingham \& Melendez, 2007) about musicians' practice is evident in the following reflections.

Reflecting back on my internship experience I can see that I have gained new insight into my profession. I saw how a professional opera company for young artists runs, which ... could help me excel as a young operatic artist, therefore giving me an advantage when I graduate. (Jolene)

It was great to hear from professional musicians their stories and how their musical career bought them to where they are today and it has definitely opened my mind and shown me other paths in music that I didn't know were there. (Jack)

I'm still not sure if I'd like to become a repetiteur, but the internship has definitely given me more knowledge that I can use to help me make a decision. In the meantime, it ... builds on and clarifies a lot of what I've been studying the Conservatorium. (Ethan)

Each of these students drew new industry knowledge from their internships and related this knowledge to possible future selves. Their openness to new ideas and career paths was shared with their lecturer in a way that might enable open discussion and support into the future.

\section{Future learning areas}

Future thinking is a sophisticated process whereby humans connect past and current experiences to a prospect of the future. Atance and O’Neill (2005, p. 126) suggest that future thinking is a unifying concept that makes connections between reflection and study and supports the ability to "project Bennett, D., Reid, A., \& Rowley, J. (2017). Student musicians' experiences of reflexivity during 10 internships: Personal narratives and complex modalities. International Journal of Music Education, 35(3), 460-475. doi: https://doi.org/10.1177/0255761416689843 
oneself into the future to pre-experience an event". Schacter et al. (2007, p. 657) indicate that during this process, "use stored information [to] imagine, simulate and predict possible future events".

The ability to 'future think' enables people to synthesise current ideas and to project—mostly positively -into the future. From a psychological perspective it can also be a precursor to depression (Lavender \& Watkins, 2004) if the future thinking outcomes fail to materialise. In this sense it is vital that students have opportunities to disperse an existing "diffuse" identity where there is little notion of what the future might hold, or to "open" a foreclosed career identity that has previously been barred to scrutiny (Marcia, 1987). In the quotations presented below, we can read generally enthusiastic future projections where musical knowledge and knowhow and the internship experience all meld towards a possible and perhaps not previously considered new future for the student. For example:

My time at the [regional conservatoire] opened my mind to the endless possibilities in the music industry and I look forward to exploring these options and finding my own path. (Jethro)

In a pedagogical context, future thinking is integrally related to future learning. In this sense, students on internship programs will, ideally, reflexively consider their past/current formal learning situations and their past/current and internship program concurrently; and finally, imagine what other experiences, skills and knowledge they need to invest in their imagined future. In the quote below, Frank demonstrates this reflexive thinking as he considers what he has learned at a radio station and how he may be able to use this in a possible film industry career.

When I do finally become a graduate of the [conservatoire], I feel [the radio station] will have helped me to develop as a creative thinker and problem-solver as a result of problems encountered solo and as part of a team. ... I would like to transfer the team skills and the effective allotment of tasks to members of a film scoring team (i.e. recording engineer, orchestrator, conductor as necessary etc.). (Frank)

Lucy focuses more on the generic skills experienced during her internship. These have impacted her thinking about her personal agency.

I have come to understand that whilst education is important to building a career, so too is work experience and learning on the job ... boosting my confidence and job skills in applying for future employment. (Lucy)

Bennett, D., Reid, A., \& Rowley, J. (2017). Student musicians' experiences of reflexivity during 11 internships: Personal narratives and complex modalities. International Journal of Music Education, 35(3), 460-475. doi: https://doi.org/10.1177/0255761416689843 
Claire expresses a different point of view. Her internship experience has enabled her to think about what she does not want to do with her musicality.

I think a large part of my problem is intention. When I create a program (for the radio) I don't begin by having a clear intent of which composers and pieces to play. I search through the catalogue and listen to CDs and choose pieces, which I find enjoyable. This internship completely stifled that natural creativity which was negative for my development as a composer/musician ... pieces that are already grouped under the banner of early music pieces from or before the Baroque don't always necessarily need another theme, and to then add another level of definition could seem superficial and unprofessional. (Claire)

For Anthony, the internship experience opened up a completely different possible work area. His imagined future is distinctly different from the city-based life he had previously expected.

Performance opportunities as both a solo pianist and choir accompanist were given to me ... I hope to return to [the regional conservatoire] and offer my services as a piano accompanist, piano tutor and music teacher in the future. (Anthony)

In the quotations that follow, students express reflexivity regarding their future thinking in relation to their possible working life focusing on different locations of employment, different types of employment, the standards required for different forms of employment, and the relationships they would wish to develop in employment. Here we see evidence of the growth mindset (Rowley \& Munday, 2014), which is what we hope to develop in student musicians for whom future work is likely to involve multiple and changing musician identities, the ability to cross borders and the necessity to step outside "the limiting frames and methods" (Davis \& Sumara, p. 35) within and outside music.

[Music's] ability to take on a form of therapy really interests me and I hope to learn more about this area in the future by working with music therapy schools. This area will allow me to work with a diverse range of children and will further develop my knowledge. (Anthony)

Over my years at the con I have learnt that the nicer you are to people and the more respect you show them, the more you will end up with a good result. ... So I immediately applied this to my internship, by openly meeting everyone, learning about them and assisting them in any way that I could. This led to a mindset for future thinking about my music career - mutual respect. (Sally) 
I also gained a significant amount of skills that have a wider application in the field of composition and music technology. For example, learning the specifications of radio audio and how it is captured and broadcast means that I not only have the direct knowledge of operating audio at a radio station, but also indirect knowledge on how to individually create a recording or composition of my own that could be tailored to radio. (Ben)

I was also exposed to the administration side of music and [I] am considering doing the Music Management unit of study offered at the conservatoire to learn more about this as I found it interesting to see how much went on behind the scenes. (Jack)

Evidenced in the above, throughout their workplace experience the student cohort engaged in multiple modalities (Whiston, Brecheisen \& Stephens, 2003) such as future-oriented thinking, self-actualisation, leadership development, meaning making, contextualisation of knowledge, purposeful engagement and change, and evolution of their personal and musical identity. Alongside those students who realised the positives of experiential learning, however, are those who did not.

\section{When reflexivity is a challenge}

A number of students were less clear about the relationship of the internship to their formal music studies, of the benefits of the work experience to learning, or about whether there were potential applications of the workplace learning after graduation. There is much to learn from those who did not take the maximum benefit from their internship experience, and this learning required us to review students' presentations alongside their written portfolio submissions.

As described, the portfolio was structured as a series of guided written reflections (Rowley \& Munday, 2014) so that students would be supported in their reflective practice (see Appendix 1). Looking at individual cases we noted that students' oral presentations were often less positive than their associated written reflections. This may have resulted from the structured format of the assessed written reflections task in contrast with the more discursive peer presentations. For example, a student placed in an arts administration internship was critical in her presentation of the pedestrian nature of the tasks required. In her written portfolio she described the tasks as "basic but valuable for understanding the operational side of an orchestra". Another student (Carrie) presented a scathing account of the inefficiencies of transport and accommodation arrangements made by a regional host organisation, whilst her written reflections told only of the professional growth she achieved through her work with 
young orchestral players. We suspect that a non-assessable, open component of students' written reflections might overcome such discrepancies. Equally, students could be actively encouraged to critique their experiences and suggest alternative or remedial actions for future cohorts.

David included a list of activities set out as calendar entries. This type of diarising was seen in $10 \%$ of the portfolios, as seen in the example from Florence:

Wednesday the 1st of May. Made it to the train, very tired, due to the realisation that the train was leaving at 7:10am, at dinner the night before, but I made it. (Florence)

Adam had a very sparse portfolio that included only a timeline of events and 55 photographs of his experience. However, he gave an insightful presentation during which he justified the photographs and their meaning to him. Adam's written reflection was a follows:

In my time in this program I attended several meetings, rehearsals, auditions and performances. (Adam)

Whilst Adam's writing might suggest he was not reflective, this might simply be a case of a student not applying himself to the task. For Adam, relevance and agency are crucial next steps.

Whilst most portfolios ranged from 12 to 20 pages, students like Adam wrote very little and reported only procedure and activities. One student (Ken) gave an interesting presentation, but he wrote only two sentences about this in his portfolio. The less reflective submissions were usually also very brief. Bowen provides such an example:

We gave workshops to local schools around each area where sometimes we performed and explained what we were doing within the music and how the students should act as listeners. I also sat in with the bands rehearsing the music that they regularly play. (Bowen)

The experience of Bowen and others led us to consider how we might offer appropriate transitional thinking to students so that workplace experiences are better positioned to prompt a shift in their thinking. We recognised that work and career "behaviours" are not taught in formal learning situations, but that they are recognised graduate capabilities (Brown \& Lent, 2013). We also noted the expectation 
that educators create opportunities for students to develop higher order thinking skills and reflective practice through authentic learning environments, and that they often do so without adequate understanding and advice about how these experiences need to be scaffolded.

In short, cases where there was minimal engagement and reflection show that for many students the skill of reflection needs to be taught and practised, even at the most basic level. As an example, when students Suri and Ken considered the challenges within their internships, they reported:

The only issue I had with this was finding the light switch for the hall. As a seemingly simple task, it took a surprisingly long time to find, as I was unfamiliar with the school's layout. When we finally found that, we gathered up the expected lost property and music and finished for the day. (Suri)

The [regional] Conservatorium of Music runs a music camp annually. This reflection of my experience working as a Buddy amongst this program was that it was hard work. (Ken)

Looking more deeply at the cases that featured functional (discursive) reporting, we realised that students had made a genuine attempt at self-reflection. Jack, for example, had tried to find an instance where he had made the connection between theory and practice. He wrote:

During all tutti orchestra rehearsals I lead by example. This included bringing a pencil to the rehearsal (and many spares for the students) something that musicians learn early on and other orchestral playing etiquette that the students hadn't come across. (Jack)

All students involved in the program could be considered as being at different stages of studenthood (despite being in similar cohort groups). Here, we need to consider that the developmental stage of studenthood is underpinned by crucial dynamic relationships with others, and that these relationships and experiences might extend forward into later development. This requires an integrated understanding of how learning applies, or might be applied to, multiple contexts. As Baker (2006, p. 182) explains, simply "holding up a mirror" to these experiences is insufficient for meaning to be made; rather, students need to "construct meaning from the disjunction between the self they thought they knew and the image they begin to recognize in the reflection they see in front of them”. 
The sparse and functional responses to the 'reflection' question indicate that for some students the internship experience was rather functional. This approach to the task is reminiscent of Marton and Saljo's (1976) surface approach to learning, or the unistructural level of Biggs and Collis' (1982) SOLO taxonomy. These theories indicate that students were focusing only on the task at hand rather than seeking to make connections between the assigned task and broader experiences. From the written material that the authors analysed, this seems to be the case. However, the written task itself may simply not engage these specific learners - evidence for this is the account of Adam who supplemented his sparse response with a series of photos, which seemed to be a more reflective outcome for him. The brief responses to the task remind us that the work experience, the formal learning task and student engagement may not necessarily afford reflexive conditions for some students.

\section{Concluding comments}

The internship program reported here offered student musicians access to authentic workplace experiences as a capstone to their formal music studies. In this paper, we explored the relation between cohort-wide, seemingly positive experiences of the internship program and the experiences of individual students. As expected, our internship data evidenced future-oriented thinking, selfactualisation, leadership development, meaning making, and contextualisation of knowledge, purposeful engagement and change, and evolution of personal and musical identity. Indeed, the student quotations presented in this paper indicated a generally positive view of the internship program.

We acknowledged earlier, however, that students engage in multiple modalities during experiential learning such as internships, and we sought a more nuanced view of student experiences through the lens of individual cases. For many students, the internship enabled a re-imagination of possible future musical selves involving the modalities of future-oriented thinking, self-actualisation, contextualisation of knowledge and meaning making. Analysis of individual cases, however, highlighted that this was not the experience of all students. Reid, Bennet and Petocz (in press) have noted that the written articulation of firm artistic identities is usually related to positive work views and professional selfefficacy, and that the descriptive narratives of workers who are confident in their identities tend to be short. In contrast, those who articulate multiple identities that are applied according to professional or social context tend to present long, engaged and sometimes-conditional narratives of lived experience. 
In some cases, lack of disclosure reveals intrinsic dissatisfaction with artistic work.

The students participating in this study showed similar written characteristics. Those students with tepid views of their internship experience (or their musical experience in general) usually wrote statements that, while reflective, were not reflexive. These statements tended to report on internship activities with little future thinking, making few connections between practice and theory, and showing only slight reflection. This leads us to conclude that work integrated learning situations such as internship programs provide different benefits to different students, and that exploration of identity might enable more students to engage in the reflexive process. Here, we note that complex modalities such as the evolution of personal and professional (musical) identity are multi-layered and fluid. As a process rather than a destination, we would expect students and indeed practitioners to engage in this evolution across their career lifespan. The focus then, is not the "completion" of a modality, but the ability of students to engage and learn from the reflexive process.

We have responded with three key "remedies" for our students. Each remedy is informed by Billett's (2011b) guidelines for integrating practice-based education, which involve essential pedagogic practices before, during and after practice-based experiences. Such practices develop students' capacities "to actively engage in, learn from and intentionally focus on their development" (Billett, 2011 b, p. 3). The first remedy involves the use of reflective phases and prompts (Boud, Keogh \& Walker, 1985) in recognition that learners' personal foundation of experience - their existing perceptions and frameworks of understanding - influence how they engage with and make meaning of each new experience. However, we note that phases and prompts alone, such as the guided questions provided to the students in this study, are not sufficient in and of themselves. As Billett (2011a) has argued, the component most often missing from practice-based learning experiences such as internships is sharing, drawing out and making sense of students' experiences once their experience is complete. Thus, our second remedy involves educators working with students as informed learning partners able to talk from and share our own experiences. This occurs in multiple forms and enables phases and prompts to be incorporated in a circular process of meaning making.

Thirdly, we deliberately guide students to become reflexive rather than reflective. Whilst critical 
reflection tends to value practice wisdom, in that an incident will produce either theory that is generalisable (Morley 2004) or theory that relates to a unique case (Schön, 1971), reflexivity focuses on individual responses and self-understandings (Ferguson, 2003). Moreover, it applies a critical lens to practice by questioning conceptual, procedural and dispositional knowledge (Healey, 2005), and it acknowledges the dynamic relationship between thoughts and feelings (Mills \& Kleinmann, 1988).

Much recent research on experiential learning positions the immersion of higher education students into the professional workplace and disciplinary field as an opportunity for individuals to learn "to adopt the values, skills, attitudes, norms and knowledge needed for membership in a given society, group or organisation” (Gardner \& Barnes, 2007, p. 3). Billett's (2004) research on workplace participatory practices identifies a number of routine levels that are either afforded or regulated within the professional environment. Among these is the logical observation that learning is a consequence of participation in social practices. This highlights MacDonald, Hargreaves and Miell's (2009, p. 465) observation that musicians' practice and identity is based on "shared understandings and practices in musical, social and cultural terms". As seen in the students' reflections, such understandings and practices were variously reported at the peripheral level, understood within the context of studenthood or, at times, troubled and reframed for future practice. Future research might seek to establish a longitudinal study of students' understanding and engagement with career modalities, perhaps incorporating a validated psychometric measure for use with individuals and teams.

For higher education students, negotiating and understanding the workplace, its expectations and organisational structure (including relationships) can be complex, difficult and time consuming. Students participate in multiple communities of practice (Wenger, 1998) including learning, musicmaking and peer communities in which they are experts, and professional communities in which they are novices (Reid et al., 2011). The instability of musicians' work indicates an element of novice-hood throughout the career lifecycle as new skills and knowledge are learned in line with each new opportunity (Hennekam \& Bennett, in press). For the students reported here, the development of professional socialisation involved workplace mentors, professional networks, and peer learning as a result of peer presentations and discussion. 
There is, however, growing acceptance that employability development is predicated not on ways of knowing - the epistemological or functional aspects of employability - but on cognitive, ontological “ways of being” (Barnett, 2007). As we have argued earlier (Bennett, 2016, p. 392), "fostering students' professional identities along cognitive dimensions with respect to their dispositions and capacities to engage as professionals concerns development of the whole individual". Through an internship, students have opportunities to make meaning that increases curiosity about self, career and learning; learner engagement; capacity for creativity and problem solving; active agency in the learning domain; and motivation to learn. This study confirms that most students need help in order for these to be realised and that this help is required before, during and especially after their internship experiences.

\section{References}

Atance, C., \& O’Neill, D. (2005). The emergence of episodic future thinking in humans. Learning and Motivation, 36(2), 126-144.

Australian Bureau of Statistics. (2010). Are young people learning or earning? ABS Australian Social Trends 4102.0. Canberra: Australian Bureau of Statistics.

Australian Collaborative Education Network. (ACEN). (2015). National strategy on work integrated learning in university education. Melbourne: ACEN.

Baker, A. (2006). What else do students need? A psychodynamic reflection on students' need for support from staff at university. Active Learning in Higher Education, 7(2), 171-183.

Barnett, R. (2007). A will to learn: Being a student in an age of uncertainty. Berkshire: Open University Press and Society for Research into Higher Education.

Bennett, D. (2012). A creative approach to exploring student identity. The international journal of creativity \& problem solving, 22(1), 27-41.

Bennett, D. (2016). Developing employability in higher education music. Arts and Humanities in Higher Education, 15(3-4), 386-395. doi: 10.1177/1474022216647388

Bennett, D., \& Bridgstock, R. (2015). The urgent need for career preview: Student expectations and graduate realities in music and dance. International Journal of Music Education, 33(3), 263-277.

Biggs, J. \& Collis, K. (1982). Evaluating the Quality of Learning: the SOLO taxonomy New York: Academic Press. 
Billett, S. (2004). Workplace participatory practices: Conceptualising workplaces as learning environments. Journal of Workplace Learning, 16(6), 312-324.

Billett, S. (2011a). Guidelines for practice: Integrating practice-based experiences. Sydney: Australian Learning and Teaching Council.

Billett, S. (2011b). Final report: Curriculum and pedagogical bases for effectively integrating practice-based experiences. Sydney: Australian Learning and Teaching Council.

Boud, D., Keogh, R., \& Walker, D. (Eds.) (1985). Reflection: Turning experience into learning. London: Kogan Page.

Bourdieu, P., \& Wacquant, L. (1992). An invitation to reflexive sociology. University of Chicago Press.

Bridgstock, R., Goldsmith, B., Rodgers, J., \& Hearn, G. (2015). Creative graduate pathways within and beyond the creative industries. Journal of Education and Work, 24(4), 333-345.

Brown, S. D., \& Lent, R. W. (2013). Career development and counseling: Putting theory and research to work. New York: Wiley.

Davis, B., \& Sumara, D. (2008). Complexity as a theory of education. Transnational Curriculum Inquiry, 5(2), 33-44.

Czikszentmihalyi, M. (2007). Developing creativity. In N. Jackson, M. Oliver, M. Shaw \& J. Wisdom (Eds.), Developing creativity in higher education (pp. xiii-xx). New York: Routledge.

D’Cruz, H., Gillingham, P., \& Melendez, S. (2007). Reflexivity, its meanings and relevance for social work: A critical review of the literature, British Journal of Social Work, 37, pp. 73-90.

Deci, E. L., \& Ryan, R. M. (1985). Intrinsic motivation and self-determination in human behavior. New York: Plenum.

Department for Business Innovation and Skills. (2013). Working while studying: A follow-up to the student income and expenditure survey 2011/12. BIS research paper number 42. London: Department for Business Innovation and Skills.

Ferguson, H. (2003). Welfare, social exclusion and reflexivity: The case of child and woman protection. Journal of Social Policy, 32(2), 199-216.

Ferns, S., Campbell, M., \& Zegwaard, K. (2014). Work integrated learning. In (S. Ferns, Ed.), Work Integrated Learning in the Curriculum, pp. 1-6. Melbourne: HERDSA.

Gardner, S. K., \& Barnes, B. J. (2007). Graduate student involvement: Socialization for the professional role. Journal of college student development, 48(4), 1-19.

Bennett, D., Reid, A., \& Rowley, J. (2017). Student musicians' experiences of reflexivity during 20 internships: Personal narratives and complex modalities. International Journal of Music Education, 35(3), 460-475. doi: https://doi.org/10.1177/0255761416689843 
Gaunt, H., \& Westerlund, H. (Eds.) (2013). Collaborative learning in higher music education: Why, What and How? Burlington, VT: Ashgate.

Gribble, C. (2014). Employment, work placements and work integrated learning of international students in Australia, Research Digest, 2.

Healey, M. (2005). Linking research and teaching exploring disciplinary spaces and the role of inquirybased learning. In Barnett, R. (Ed.), Reshaping the university: New relationships between research, scholarship and teaching. Maidenhead: McGraw-Hill/Open University.

Hennekam, S., \& Bennett, D. (In press). (Self)managing complexity: Managing work in the Netherlands creative industries. International Journal of Arts Management. Accepted June 2015.

Lavender, A., \& Watkins, E. (2004). Rumination and future thinking in depression. British Journal of Clinical Psychology, 43(2), 129-142.

Lebler, D. (2008). Popular music pedagogy: Peer learning in practice. Music Education Research, 10(2), 193-213.

MacDonald, R. A. R., Hargreaves, D. J., \& Miell, D. E. (2009). Musical identities. In Hallam, S., Cross, I., \& Thaut, M. (Eds.), The Oxford handbook of music psychology. Oxford: OUP.

Manson, S. (2001). Simplifying complexity: A review of complexity theory. Geoforum, 32(3), 405414.

Marcia, J. (1966). Development and validation of ego-identity status. Journal of Personality and Social Psychology, 3(1), 551-558.

Marton, F. \& Saljo, R. (1976). On qualitative differences in learning - 1: Outcome and process. British Journal of Education Psychology, 46, 4-11.

Mason, B. (2014). Journalism practice and critical reflexivity: A death in custody interview. Pacific Media Review, 20(1), 158-79.

Mason, G., Williams, G., \& Cramner, S. (2009). Employability skills initiatives in higher education: What effects do they have on graduate labour market outcomes? Education Economics, 17(1), 1-30.

Mills, T \& Kleinman, S. (1988). Emotions, reflexivity and action: An interactionist analysis, Social Forces, 66(4), 1009-27.

Morley, C. (2004). Critical reflection in social work: A response to globalisation? International Journal of Social Welfare, 13(4), 297-303.

Piihl, J., Rasmussen, J., Rowley, J. (2015). A multi-disciplinary framework for building students'

Bennett, D., Reid, A., \& Rowley, J. (2017). Student musicians' experiences of reflexivity during 21 internships: Personal narratives and complex modalities. International Journal of Music Education, 35(3), 460-475. doi: https://doi.org/10.1177/0255761416689843 
capacity as practitioner researchers. In Guerin, C., Bartholomew, P., \& Nygaard, C. (Eds.), Learning to research, researching to learn, (pp. 39-58). Faringdon, Oxfordshire: Libri Publishing.

Reid, A., Abrandt Dahlgren, M., Petocz, P., \& Dahlgren, L. O. (2011). From expert student to novice professional. Springer: Dordrecht.

Reid, A., Bennett, D., \& Petocz, P. (In press). Creative workers' perceptions of worth: Understanding identity and motivation in a complex workforce. Australian Journal of Career Development. Accepted December 2015.

Rowley, J., Bennett, D., \& Reid, A. (In press). Leadership as a core creativity for musician identity. In (Chong, E., Ed.), Proceedings of the $21^{\text {st }}$ international seminar of the ISME Commission for the Education of the Professional Musician. St Andrew's University, Scotland, July.

Rowley, J., \& Munday, J. (2014). A sense of self through reflective thinking in ePortfolios. International Journal of Humanities Social Sciences and Education, 1(7), 78-85.

Schacter, D., Addis, D. R., \& Buckner, R. L. (2007). Remembering the past to imagine the future: The prospective brain. Nature Reviews in Neuroscience, 8, 657-661.

Schön, D. A. (1971). Beyond the stable State: Public and private learning in a changing society. London: Maurice Temple Smith Ltd.

Schön, D. A. (1983). The reflective practitioner. New York: Basic Books.

Solomonides, I., \& Reid, A. (2009). Variation in student engagement: A design model. Pedagogical Research Maximising Education, 3(2), 115-128.

Wenger, E. (1998). Communities of Practice: Learning, meaning and identity, CUP: Cambridge.

Whiston, S., Brecheisen, B., \& Stephens, J. (2003). Does treatment modality affect career counseling effectiveness? Journal of Vocational Behavior, 62(3), 390-410.

Wren S., \& Wren, D. (2009). Enhancing learning by integrating theory and practice. International Journal of Teaching and Learning in Higher Education, 21(2), 258-265.

\section{Appendix 1: Guiding questions for students completing the internship portfolio*}

\section{Professionalism}

What do you think you will do at the host organisation?

What would you like to learn, and why?

What do you hope to offer your host organisation?

Bennett, D., Reid, A., \& Rowley, J. (2017). Student musicians' experiences of reflexivity during 22 internships: Personal narratives and complex modalities. International Journal of Music Education, 35(3), 460-475. doi: https://doi.org/10.1177/0255761416689843 


\section{Summary of learning}

What do you expect to learn on the first day?

What are your first impressions of the organisation and why?

What events and activities did you take part in with staff at the host organisation?

How did this impact on the learning during your internship?

\section{Learning objectives and outcomes}

How could you further extend your skills and knowledge you gained during the internship?

\section{Relating theory, policy and practice}

What connections have you made from your lectures and tutorials that have become more applied after your internship? Give an example of this connection

\section{Self-reflection}

How have you changed or gained new insight into your profession as a result of the internship?

\section{Future Learning Areas}

How do your future learning goals link to your internship and your learning outcomes?

* Adapted from Rowley and Munday (2014)

Bennett, D., Reid, A., \& Rowley, J. (2017). Student musicians' experiences of reflexivity during 23 internships: Personal narratives and complex modalities. International Journal of Music Education, 35(3), 460-475. doi: https://doi.org/10.1177/0255761416689843 